\title{
陽極酸化アルミニウム膜による片持ち梁の製作
}

$\begin{array}{llrl}\text { 正員 } & \text { 佐藤 } & \text { 洋一 } & \text { （東海大学短期大学部） } \\ \text { 非会員 } & \text { 岡田 } & \text { 工 } & \text { （東海大学短期大学部） } \\ \text { 非会員 } & \text { 崔 } & \text { 一煐 } & \text { (東海大学短期大学部) } \\ \text { 正員 } & \text { 飯田 } & \text { 昌盛 } & \text { (東海大学工学部) }\end{array}$

\section{Fabrication of Micro-Cantilever Beams Using Anodic Oxidized Aluminum}

Yoichi Sato, Member, Takumi Okada, Non-member Il Yong Choe, Non-member

(Tokai University. Jr. College) Masamori lida, Member (TokaiUniversity)

A new fabrication process of micromachines using anodic oxidized aluminium film has been developed.

The aluminium oxide film was made by anodizing evaporated aluminium in $\mathrm{H}_{2} \mathrm{SO}_{4}$ solution with a constant voltage. For examples, a cantilever beams have been fabricated which is deflectable by electrostatics. And the Yong's modulus is determined from the resonance frequency of these beams, $\mathrm{E}=327 \mathrm{GPa}$. From these results, we therefore conclude that anodic oxidized aluminium film is a good material of micromachines.

キーワード：マイクロマシン, アルミニウム, 陽極酸化, 多孔質, 片持ち梁

\section{1.まえがき}

アルミニウムを陽極酸化することによって、その表面に 酸化アルミニウム皮膜（アルミナ膜）が生成されること は、アルマイト処理として古くからよく知ら扎ていること である(1)。

この処理において、使用する浴液によって表面に小さな 孔が無数にある多孔質の皮膜を生成する場合と、孔が無く 薄く堅い層である無孔質の皮膜を得る場合がある。この皮 膜はどちらも絶縁物である。酸性浴液中で処理すると、生 成した皮膜の一部は溶解しながら反応が進行するので、多 孔質の酸化アルミニウム皮膜ができる。したがって、アル ミニウム全部を酸化アルミニウムに変えてしまうような厚 い膜を作ることも可能である。また途中で反応を停止する ことにより、表面から所定の厚さまでを多孔質層にするこ とも時間の制御で可能である。一方、中性の浴液中で処理 すると、生成した皮膜は溶解しないので電流は流れなくな り反応は停止する。これら一連の処理は常温程度の低温で の処理が可能である。これらの特徵に着目し、筆者らはア ルミニウムの陽極酸化によって得られる酸化アルミニウム 膜を、マイクロマシンの構造材料に利用する試みとして片 持ち梁を製作、その特性を測定し良好な結果を得たので報
告する。この様な例は報告されておらず、初めての報告で ある。

2.アルミニウムの陽極酸化と酸化アルミニ ウム膜の特徵

アルミニウムは柔軟性に富み加工しやすい金属である。 このため、集積回路を初め多くの電子素子の形成には必要 欠くベからざる金属になっている。アルミ二ウムは非常に 活性な金属でありすぐ酸化物に変わる。酸化物の生成熱は 大きい。このこしは、酸化アルミニウムが安定であり、ア ルミニウムはしたがって酸化物になろうとする傾向が極め て強いことを示している。したがって、アルミニウムは空 気中で急速に酸化され、表面に薄い酸化アルミニウム皮膜 を生成する。すなわちアルミナ膜である。この膜は非常に 安定していることから、一旦この膜で覆われたアルミニウ ムの酸化はこれ以上は進行しない。

この性質を利用して、人工的に酸化アルミニウム膜をア ルミニウム表面に生成するのがアルマイト処理である。而 蝕性を增すこの技術はアルミニウムの用途を大きく拡大し た。最近は、この脱が多孔性であることを利用して、この 孔の中に着色料を浸瀆させることによってカラーアルミニ 
ウムを作り、新素材として建築資材など様々な分野に大量 に使用されている(2)。また、この多孔質膜と無孔質膜とを 上手に組み合わせることにより、LSIに必要な多層配線 を実現した例(3)や、液晶用のTFTに利用した例(4)など もある。

無孔性酸化膜の生成は

$2 \mathrm{Al}+3 \mathrm{H}_{2} \mathrm{O} \rightarrow \mathrm{Al}_{2} \mathrm{O}_{3}+6 \mathrm{H}^{+}+6 \mathrm{e}$

に従う(1)。この反应は化学量論的反応であり、生成する皮 膜の厚みは通電量に比例し、以下に示す理諭式で表わすこ とができる。皮膜の厚みをdとすと

$\mathrm{d}=(\mathrm{M} / 6 \mathrm{~F} \rho) \times \mathrm{I} \mathrm{t}$

ここで、F：ファラデー定数、I : 通電量、 $\rho$ :

$\mathrm{Al}_{2} \mathrm{O}_{3}$ の密度、 $\mathrm{M}: \mathrm{Al}_{2} \mathrm{O}_{3}$ の分子量、 $\mathrm{t}$ ：

通電時間

で与えられる。(1) 多孔性の酸化膜は、上記の反応で生成し た膜が、酸に溶解することで得られるので、アルミニウム を陽極上して硫酸、しゅう酸などの酸性浴液中で陽極酸化 する。(1)この膜は最初に無孔質層が生じ、その後核となる 部分を中心に微紼孔が発生し、この孔を通して浴液中のア ニオンが下のアルミニウム面に到達してさらに反応が進む と若えられている。このプロセスが継続することで厚い層 が得られる。この多孔質層の厚み注全体の厚みの90\%以上 を占めるほど厚いのが普通である。生成した膜の構造につ いてはF.Kellerらによりモデルが提案されている(5)。これ によると、面に対して垂直な多数の微細孔（pore）を持つ厚 い多孔質層（Porous layer）亡、その下のアルミニウムとの境

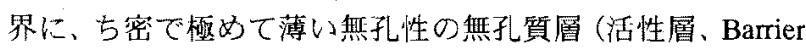
層などしもよばれる）上から成っている。多孔質層は中央 に微細孔を持つ長い六角柱のセルが密集している構造を持 つ。この微細孔のサイズは、浴液、電流密度、印加電圧など により一定となると言われている。また、微細孔と微細孔 との間隔も一定で、規則正しい配列をしている。

一方、無孔質の活性層のみを得るには、ほう酸アンモ二 ウムのような中性の浴液中で陽極酸化を行う。この場合は、 酸による溶解作用が無いので、膜が生成するにつれて供給 電流は急速に減少し、やがて反応が終了する。この膜の成 長は、印加電死にほぼ比例し、浴液の濃度や温度、時間には

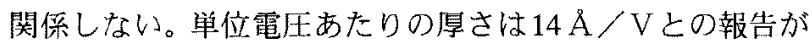
ある(5)。

以下、筆者らが行った陽極酸化の方法について述べる。

図 1 に示すように、10\%硫酸（重量％）溶液中に、99.99\% のアルミニウムが蒸着されたウエハと白金電極とを、間隔 約 $3 \mathrm{~cm}$ で対向するようにビーカー中にセットし、10 Vの 定電圧を印加した。ウ工八側の電極はアルミニウム表面か らとった。ウエハは蒸着してあるアルミニウムの表面から のみ電流が流れ、反応が表面から進行するように、あらか じめウ工八全面を酸化膜で覆った。浴液つ温度を $25 \sim 30^{\circ} \mathrm{C}$ に保ち、照明は通常の室内光で行った。陽極酸化される表 面積は $2.25 \mathrm{c} \mathrm{m}^{2}(1.5 \mathrm{~cm} \times 1.5 \mathrm{~cm})$ とした。図 2 に処理電流 の時間変化を示すが、電流は反応が進むにつれて減少し，
やがて一定の值となり反応は停止する。反応時にはアルミ ニウム表面に気泡がつくので、弱い超音波槽に入れるのも 効果的である。終了後はただちに純水で十分洗浄する。

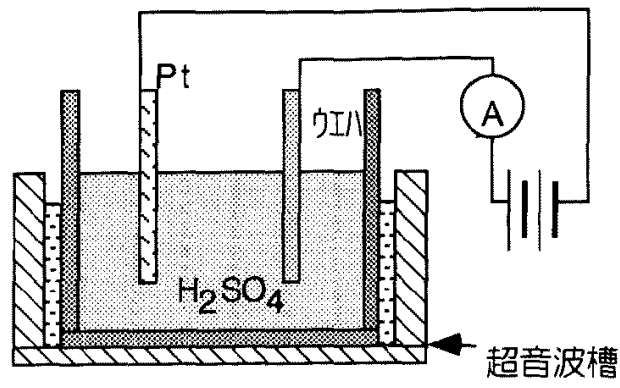

図 1 .陽極酸化の装置

Fig .1. Experimental setup

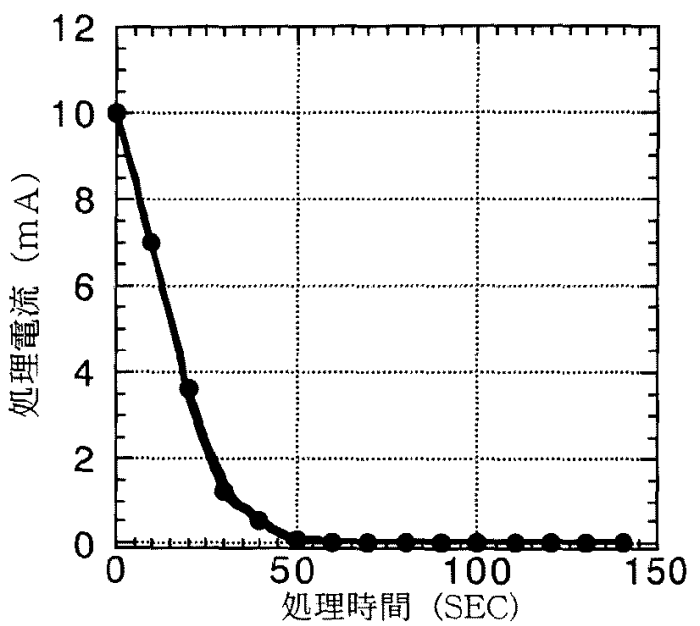

図 2 陽極酸化電流亡処理時間

Fig.2. Relation between forming current and time.

\section{3.片持ち梁の製作}

片持ち梁はマイクロマシンとして多くの研究報告がなさ れている(6)。ポリシリコン、シリコン酸化膜、あるいは異 方性エッチングを用いてシリコンの単結晶を薄膜状にして 梁を作る例、またこれらの材料を組み合わせた例、またシ リコンを陽極酸化して得られる多孔質シリコンを利用した ブリッジなどの例がある(7)。

筆者らは、これまでに述べた多孔質層の厚い酸化アルミ ニウムを、マイクロマシンの構造材料しして使用する試 として、静電駆動型の片持ち梁を製作しその振動特性を測 定した。図 3 に製作した片持ち梁の断面形状と代表的な平 面形状を示す。梁は同一寸法のもの三本を一組とした。梁 の長さは、500、600、700、800、900 $\mu \mathrm{m} の 5$ 種類とした。 梁の幅は $80 \mu \mathrm{m}$ である。

以下、プロセスを図 4 に示す断面図を用いて説明する。 基板にはシリコンウエハを用いた。シリコン基板を酸化し 
表裏全面に薄い酸化膜を生成する。この酸化膜は、絶縁性 を保つことが目的であるのでそれほどの厳密さは要求され

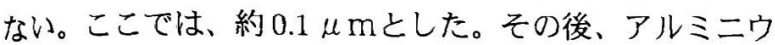
厶を約 $0.2 \mu \mathrm{m}$ の厚みに抵抗加熱による真空蒸着を行い、 ポジ型フォトレジストAＺ１３５０により下部電極となる パターニングをした。その後、図1の装置を用いてウエハ 倒を陽極、白金を㓌極として $10 \%$ 硫酸中で陽極酸化を行っ た。印加電圧は $10 \mathrm{~V}$ 一定とした。レジストで覆われてい た場所はアルミニウムのまま残り、それ以外の部分は透明

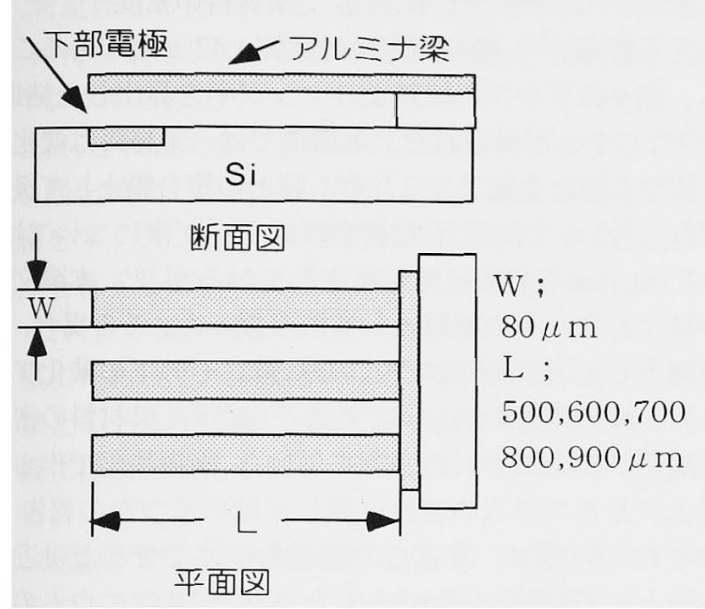

図 3 片持ち梁の寸法

Fig.3. Dimension of cantilever beams.

な多孔質の膜が生成し絶縁物に変わる。図 5 に下部電極が 完成した写真を示す。さらに中性であるほう酸アンモニウ ム $3 \%$ （重量％）浴液中、電圧 $80 \mathrm{~V}$ で陽極処理した。こう することによって、アルミニウム電極間の絶縁而压は向上 する。これはアルミニウムと多孔質層境界部分 (この場合 は電極の側面になる)のアルミニウム面に、絶縁性の良い 無孔質の層が生成するためである。次に、梁と下部電極の 間隙を作るために、沓ジ型フォトレジストAＺ４６２０を 約 $1.3 \mu \mathrm{m}$ の厚みに塗布した後、片持ち梁の柱となる部分 のパターニングを行った。このフォトレジストは辇牲層に もなるものである。ポジ型レジストを使用したのは、犠牲 層としてのレジストを除去するとき、有機溶郕が使用でき ることを考虑してのことである。つづいてアルミニウムを 約 $1.4 \mu \mathrm{m}$ の厚さ真空蒸着し、再び陽極酸化処理により全 体を酸化アルミニウム膜に変え、さらに上部の電極となる アルミニウムを約 $0.1 \mu \mathrm{m}$ 蒸着したのち、フォトレジスト により梁形状にパターニングし、 $\mathrm{H}_{3} \mathrm{PO}_{4}: \mathrm{H}_{2} \mathrm{O}=1$ : 1 、液温 $60^{\circ} \mathrm{C}$ のエッチャントにより上部のアルミニウム と、その下の酸化アルミニウム層を同時にエッチングし た。その後アセトンに浸漬し犠牲層であるフォトレジスト を除去した。図 6 に完成した片持ち梁を示す。梁の先端 が影になっており反り上がっていることが分かる。

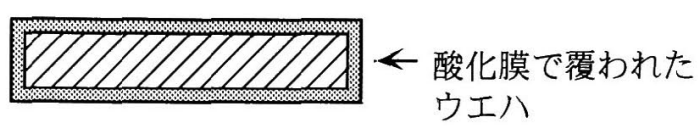

下部アルミ電極
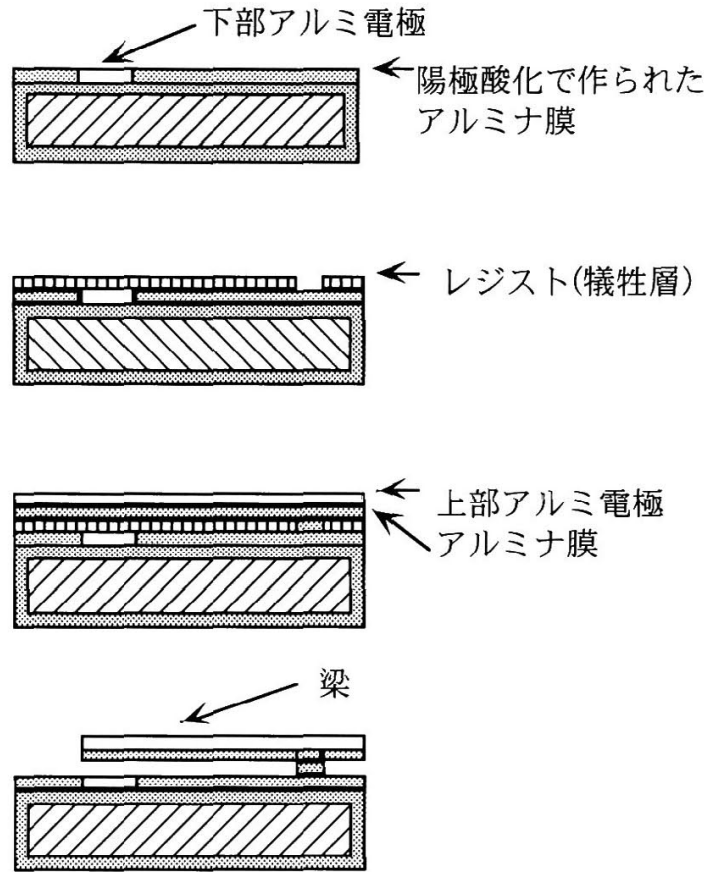

図4. 片持ち梁の製作プロセス

Fig. 4. Process sequence of cantilever beams

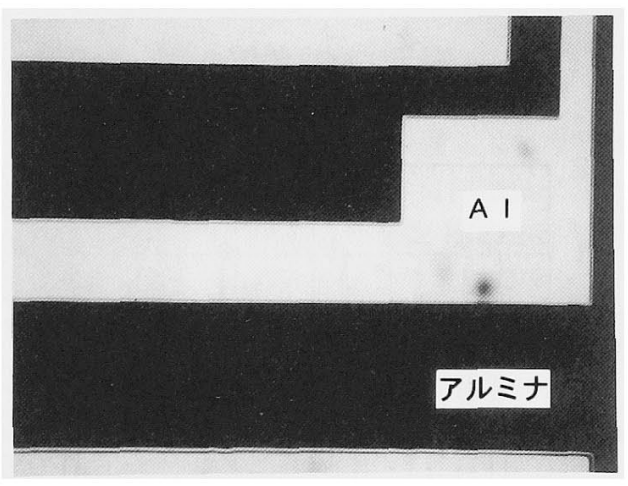

図 5 下部電極

Fig.5. Photograph of under electrodes.

\section{4. 梁の振動特性と解析}

試作した片持ち梁の振動特性を測定した。測定は図 7 に 示すように、 H e - N e レーザを梁に照射し、梁と下部電 極間にパルス電圧を印加し梁を振動させ、そのときスケー ル上に現われる反射光の位置変化を読み取る方法で行っ た。印加電圧は $20 \mathrm{~V}$ とし、周波数範囲は $1 \mathrm{H} \mathrm{z} \sim 1 \mathrm{MHz}$ 迄の矩型波とした。発信器と片持ち梁の間に、高耐圧MO Sトランジスタを使用したインバー夕回路を挿人すること で高い電圧を得るようにした。インバー夕回路の出力波形 


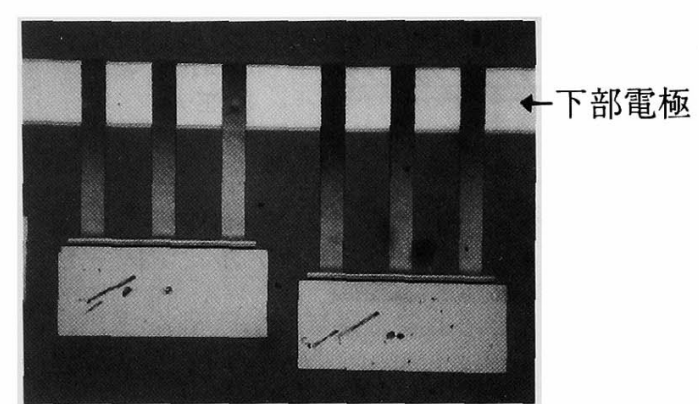

図 6 完成した片持ち梁

Fig. 6. Photograph of cantilever beams.

は0〜+Vの矩型波であり、1 周期で 1 回の振動が起こる。

図 8 に梁の長さとそれぞれの振動特性を示す。縦軸の振 幅を示すスケールは、共振点に達した時に現われる位置変

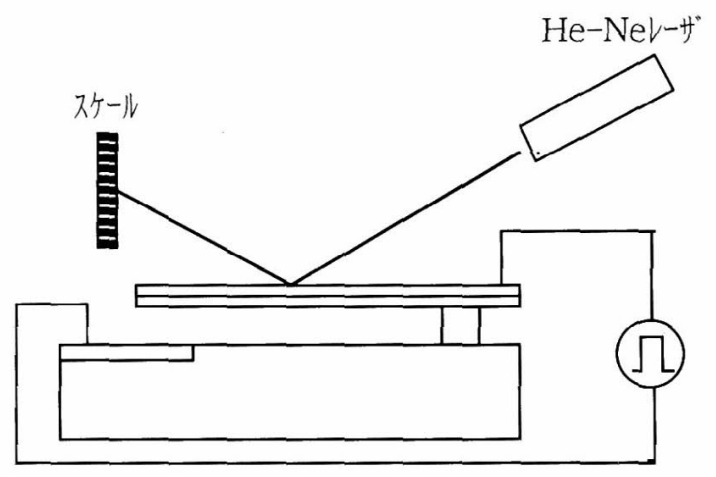

図 7 測定装置

Fig. 7. Measurement set up

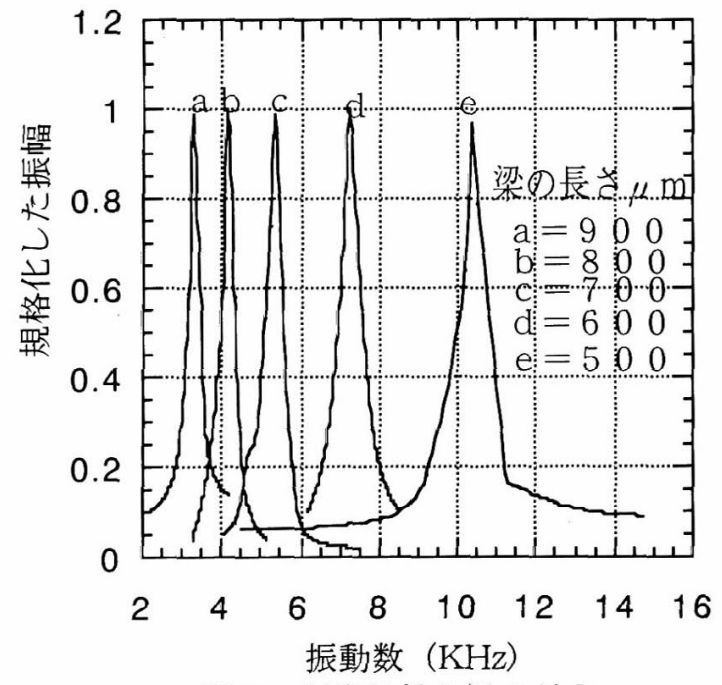

図 8 振動特性と梁の長さ

Fig.8. Typical vibrational behavior for five beams of different length.

化の最大值を用いて規格化したものである。梁の長さが短 くなるにつれて共振周波数が高くなっているのがみられ
る。また、最も短い $500 \mu \mathrm{m}$ の長さを持つ梁について、共 振の鋭さを表わす值であるQ値を推定した。その結果、Q 值は約 13 程度の小さい值を示した。ここでのQ值は半値 幅と、共振周波数との比とした。また図 9 に梁の長さと共 振周波数の関係を示す。横軸は $1 / \mathrm{L}^{2}$ にとつた。ここで Lは梁の長さである。このような片持ち梁の共振周波数は 1 次モードの場合

$$
\begin{aligned}
& \mathrm{f}=0.162 \mathrm{t}(\mathrm{E} / \rho) 1 / 2 / \mathrm{L}^{2} \\
& \text { ここで、 } \mathrm{f}: \text { 振動数、 } \mathrm{t}: \text { 梁の厚さ、 } \mathrm{L}: \text { 梁の }
\end{aligned}
$$

長さ、 $\mathrm{E}$ : ヤング率、 $\rho$ : 梁材料の密度 で与えられる。〈8）梁の厚さ $\mathrm{t}$ は実測 $1.42 \mu \mathrm{m}$ であること から、図 9 のグラフの傾斜よりヤング率を算出した結果、 $\mathrm{E}=327 \mathrm{G} P$ a が得られた。本構造では、梁材料は酸化ア ルミニウム膜と金属アルミニウム膜との複合膜として扱わ ねばならない。このような複合膜のヤング率については、 Kurt E.Petersen らによって解析されているが(8)、本論文で は一体化した一つの材料として取り扱つた。この場合、上 部電極としてのアルミニウムの厚みは、その下の酸化アル ミニウム膜の厚さの約 $1 / 14$ であることから、梁材料の密度 には酸化アルミニウムの密度を用いた。陽極酸化で作られ た酸化アルミニウムの密度に関してはいくつかの報告 (9) がなされているが、筆者らの処理条件にできるだけ近い データとして $3.0 \mathrm{~g} / \mathrm{c} \mathrm{m}^{3}$ とした(10)。アルミニウムのヤ ング率は $70.3 \mathrm{GPa}$ (11)、酸化アルミニウムのヤング率は、 焼結形の高純度アルミナセラミックの值として 350～400 G P a (1 2) が報告されている。筆者らが得た值はやや小 さな值であるが、これに近く妥当な值と考える。なお今後 さらに詳細な検討が必要と考えている。

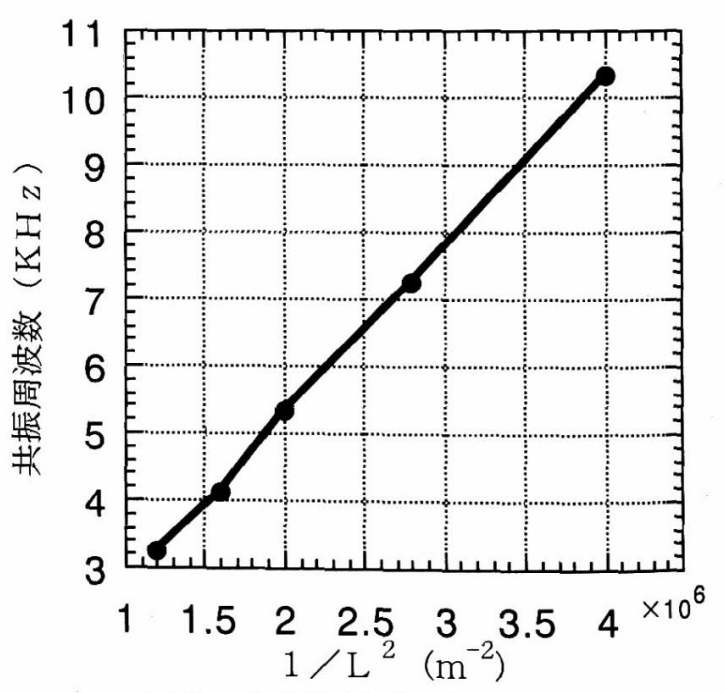

図 9 共振周波数と梁の長さ

Fig.9. Relation between resonant frequency and reciprocal of square beam length. 


\section{5.むすび}

本研究は、蒸着アルミニウムを陽極酸化することで得 られた多孔質膜を、マイクロマシンの構造材料として使用 することの試みを片持ち梁を製作することで示したもので ある。この結果、以下に述べる成果を得ることができた。 1.マイクロマシンの構造材料としての使用は可能である こと。

2 .犠牲層としてレジストなど有機材料の使用が可能であ ること。

3 . 常温程度の比較的低い温度プロセスが得られること。 4.片持ち梁として、振動特性を測定し、複合膜としての ヤング率を推定することができた。

また、これまで多く使用されているポリシリコンやシリ コン酸化膜などの材料と比較して、アルミニウムの陽極酸 化膜をマイクロマシンの構造材料に使用することは多くの 利点を有するが、特に以下の 3 項目が揚げられる。

1.これまで犠牲層として多く使われていたシリコン酸化 膜に代わって、有機材料などが使用できるので、集積回 路との一体化の際に、回路素子表面を保護している酸化 膜に損傷を与えることが無く、プロセス設計が容易とな る。

2. 低温度プロセスであることから、集積回路と一体化す ることが容易である。これまで多く使用されているポリ シリコン、シリコン酸化膜を材料とすると、その処理温 度には数百度以上が必要となる。このことは集積回路と の一体化を考えるとき、プロセス設計の幅がせまくな

る。その点この方法はほぼ常温処理なので、プロセス 設計の幅が広くとれ有利である。

3 .多孔質のアルミニウム酸化膜は、処理を加えることに より、多くの機能を付加することができ(13)、新しい機 能を持つマイクロマシン開発の可能性がある。

など多くの特徵、利点を持っている。

一方、梁の形状を作るエッチング時のサイドエッチ、梁 の反り、梁表面の平坦度、犠牲層として用いたレジストの 変質程度などの問題があり、これからの課題として残され ている。また膜の結晶構造、機械材料としての様々な物 性、信頼性などプロセスとの関係で大きく変動することも 考えられるが、これらも今後の検討課題である。

最後に、本研究に協力いただいた東海大学研究生長島祥 子、東海大学卒研生竹内利彦 (現三益半導体 (株))、同卒 研生谷口秀之の諸氏に感謝する。

(平成 7 年 11 月 24 日受付、平成 8 年 3 月 1 日再受付)

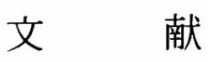

（1）社団法人 電気化学協会編: “電気化学便覧”, (1969)

（2）神尾彰彦: “アルミニウム新時代”, 工業調査会 (1993)

（3）野口忠雄、石野寛、佐藤洋一、篠塚勝正 : “ミニコン の 1 ボードC P Uの研究について”, 電子通信学会技
術研究報告, S S D 75-23，(1975）

（4）塚田俊久、山本英明 : “高歩留まりと低配線抵抗を両 立、液晶向け陽極酸化 ALゲートTFT”, 日経マイクロ デバイス，107，3月，(1991）

( 5 ) F.Keller,M.S.Hunter,D.L.Robinson : "Structural Features of Oxide Coatings on Aluminium" ,J.Electrochem.Soc., 100,9, (1953)

(6) R.T.Howe and R.S.Muller : "Polycrystalline Silicon Micromechanical Beams” ,J.Electrochem.Soc.,130,6, (1983)

（7）渡辺一仁、崔一煐、佐藤洋一、飯田昌盛: “酸化多孔 質シリコンを用いたマイクロブリッジの製作”, T.IEE Japan,Vol.112-A,NO.12, (1992)

(8) Kurt E.Petersen and C.R. Guarnieri : “Yong's modurus measurements of thin films using micromechanics" , J. Appl. Phys.,50.11 (1975)

(9) G.Paolini,M.Masoero,F.Sacchi and M.Paganell : “An Investigation of Porous Anodic Oxide Films on Aluminum by Comparative Adsorption, Gravimetric and Electronoptical Measurements", J.Electrochem.Soc.,112,32, (1965)

（１００）海老原 健, 高橋 英明, 永山 政一：“硫酸中 で生成したポーラス型アルミニウムアノード酸化被膜 の構造と密度”，金属表面技術，33，4，(1982）

（1 1 ）東京天文台編纂: “理科年表”,（1993）

(1 12 ) サイエンスフォーラム: “ファインセラミックス利 用技術集成一精密加工、設計、評価技術一”，(1982)

（1３）礒山永三、室岡秀一: "アルミニウムの表面処理”, 軽金属, No.6, Vol.40, (1990)

佐藤洋一（正員）昭和35年3月東北大学理学部物理学科

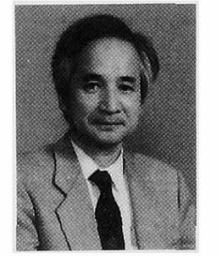
卒業。同年 4 月沖電気工業 (株) 入社。 平成元年東海大学短期大学部教授。現 在に至る。マイクロマシン、半導体デ バイスの研究に従事。応用物理学会、 応用科学学会会員。

岡田工 (非会員) 昭和 41 年 12 月 30 日生まれ。平成 4 年

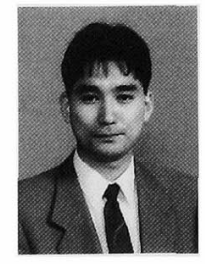
3 月東海大学大学院工学研究科修士課 程終了、同年東海大学短期大学部助手。 面発光型半導体レーザ、マイクロマシ ンの研究に従事。応用物理学会会員。

崔

一煐（非会員）昭和 30 年 10 月 11 日生。59年 3 月東

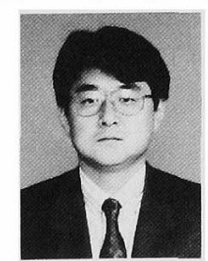
海大学大学院工学研究科博士課程終 了。同年7月同大学開発技術研究所助 手、62年 4 月同大学短期大学部講師、 平成 6 年 4 月同助教授、現在に至る。 工学博士。深い不純物準位を有するシ 究に従事。応用物理学会、電子情報通 
信学会、IEEE 会員。

飯田昌盛 （正員） Vol.112-A,NO.12, (1992) 